\title{
KEADAAN EKONOMI RUMAHTANGGA PETANI JAMBU METE DI KABUPATEN BUTON SULAWESI TENGGARA
}

\author{
(Household Economic Condition of Cashew Farmer In Buton Regency Southeast \\ Sulawesi)
}

Wa Ode Yusria

Jurusan Sosial Ekonomi Pertanian

Fakultas Pertanian Universitas Haluoleo Kendari

\begin{abstract}
The research is aimed to investigate an economic welfare of cashew farmer household in Buton regency economically. This study has been done in Buton regency. Research area is selected purposively with 60 farmers selected as respondents with consideration whose can speaks Indonesian and willing for interviewed. Data are analyzed using regression model approach. The result of this study showed that cashew farmer householsd in Buton regency economically were wealth and non poor farmers as indicated by good service ratio (GSR) of 0.99865.

Key words: Household welfare, cashew farmer, good service ratio
\end{abstract}

\section{PENDAHULUAN}

\section{Latar Belakang}

Dewasa ini pembangunan di sektor pertanian akan terus dikembangkan agar semakin maju dan efisien, sehingga kualitas dan kuantitas produktivitas semakin meningkat pula. Untuk mencapai sasaran tersebut maka perlu dilaksanakan empat usaha pokok dalam pertanian yaitu: intensifikasi, ekstensifikasi, diversifikasi dan rehabilitasi.

Pembangunan pertanian yang dilaksanakan selama ini mencakup pembangunan subsektor pertanian tanaman pangan, peternakan, perikanan dan perkebunan yang arahnya bertujuan untuk meningkatkan produksi guna memenuhi kebutuhan dalam negeri dan peningkatan ekspor.

Jambu mete (Anacardium Occidentale L) adalah salah satu komoditas perkebunan yang termasuk mata dagangan yang mempunyai peranan penting dalam perolehan devisa maupun sebagai lapangan kerja dan sumber mata pencaharian utama bagi sebagian besar penduduk di beberapa propinsi. Tanaman Jambu mete mempunyai potensi cukup besar untuk dikembangkan di 
daerah-daerah beriklim kering, pada lahan kritis marjinal terutama di Kawasan Timur Indonesia.

Kebijakan pengembangan usahatani jambu mete secara ekonomi mempunyai sasaran: (1) Meningkatkan produksi dan kualitas untuk konsumsi dalam negeri dan ekspor non migas. (2) Meningkatkan nilai tambah melalui diversifikasi hasil utama, hasil sampingan dan manfaat limbah. (3) Meningkatkan pendapatan dan kesejahteraan petani daerah minus sekaligus dampak penyerapan tenaga kerja.

Berdasarkan keadaan tersebut maka pembangunan lebih ditekankan kepada upaya peningkatan kesejahteraan masyarakat perdesaan. Untuk mendukung tujuan pembangunan tersebut diperlukan potensi sumberdaya alam yang optimal, sumberdaya manusia yang berkualitas dan produktif serta pemanfaatan ilmu pengetahuan dan teknologi dengan tidak mengesampingkan kelestarian lingkungan hidup.

\section{Tinjauan Pustaka}

\section{Sistem Usahatani Jambu Mete}

Jambu mete merupakan salah satu tanaman yang cukup banyak dikembangkan di Sulawesi Tenggara. Awalnya tanaman ini hanya digunakan sebagai tanaman penghijauan yang berfungsi memperbaiki lingkungan. Tetapi karena memiliki prospek yang cerah dan nilai ekonomi yang tinggi, maka petanipun menjadikan tanaman ini sebagai salah satu sumber pendapatan yang meningkatkan perekonomian petani. Hal ini terlihat pada animo masyarakat Sulawesi Tenggara yang mengusahakan tanaman, luas areal tanaman jambu mete di Sulawesi Tenggara mengalami peningkatan dari tahun ke tahun secara signifikan, begitu juga dengan produksinya (Anonim, 2008). Namun tentu saja dalam hal produksi tidak lepas dari berlakunya hukum The Law of Diminishing Return.

Pola pengusahaan tanaman jambu mete oleh petani di Sulawesi Tenggara sebagian besar berbentuk pola perkebunan rakyat. Pola ini diharapkan dapat mendukung perekonomian rakyat melalui peningkatan pendapatan petani yang sekaligus merupakan pemerataan pembangunan khususnya dalam sektor pertanian.

Secara umum pola perkebunan rakyat bertujuan untuk meningkatkan produksi baik ditinjau dari jumlah maupun mutu yang dihasilkan, juga peningkatan pendapatan petani. Peningkatkan pendapatan petani tersebut akan 
memacu petani untuk berpartisipasi dalam upaya meningkatkan produksi dan kualitas melalui usahataninya

\section{Pendapatan Rumah Tangga Petani}

Rumah tangga memiliki sumber pendapatan untuk memenuhi kebutuhan hidupnya, yaitu yang disebut sebagai pendapatan rumah tangga. Pendapatan rumah tangga tersebut merupakan pendapatan kepala rumah tangga dan anggota keluarga menurut mata pencaharian per satuan waktu.

Pendapatan rumah tangga adalah kumpulan dari pendapatan anggotaanggota rumah tangga dari masing-masing kegiatannya. Pada sebagian rumah tangga pertanian usaha pertanian masih merupakan sumber penghasilan, tetapi bagi sebagian rumah tangga petani yang lain, usaha selain pertanian lebih menunjang kebutuhan hidupnya. Pendapatan rumah tangga pertanian tidak hanya berasal dari usaha pertanian tetapi juga dari luar sektor tersebut seperti perdagangan, industri pengangkutan dan sebagainya (BPS, 2008) berdagang, buruh bangunan, tukang kayu, perangkat desa, dan lain-lain.

Usahatani dapat dikatakan berhasil jika menggunakan perhitungan dengan pendekatan profit (keuntungan) memenuhi syarat-syarat sebagai berikut(Hadisapoetro, 1973).

1. Dapat menghasilkan cukup pendapatan untuk membayar semua alat-alat yang diperlukan.

2. Dapat menghasilkan pendapatan yang dapat dipergunakan untuk membayar bunga modal yang dipergunakan dalam usahatani tersebut, baik modal sendiri maupun pinjaman.

3. Dapat membayar upah tenaga kerja petani dengan keluarganya yang dipergunakan dalam usahatani secara layak

4. Dapat membayar tenaga petani sebagai manajer yang harus mengambil keputusan dalam usahataninya.

Onchan dan Chalamwong dalam Dampa (2003) mengemukakan bahwa ada tiga sumber penghasilan rumah tangga yaitu : 1) dari kegiatan farm atau usahatani, 2) dari non farm yaitu kegiatan perusahaan, pekerjaan upahan pada usahatani orang lain dan perusahan-perusahaan pertanian, 3) lain-lain yaitu kegiatan lain selain (1) dan (2) tersebut. Selanjutnya mengemukakan bahwa semua aktivitas yang bisa mendatangkan penghasilan yang dilakukan di luar kegiatan usahataninya sendiri disebut off farm activities 


\section{Kesejahteraan}

Tingkat kesejahteraan rumah tangga secara nyata dapat diukur dari tingkat pendapatannya yang dibandingkan dengan kebutuhan minimum untuk hidup layak. BPS (2008), menjelaskan bahwa determinan utama tingkat kesejahteraan ekonomi penduduk adalah daya beli, sehingga apabila daya beli menurun maka berdampak pada menurunnya kemampuan untuk memenuhi pelbagai kebutuhan hidup sehingga tingkat kesejahteraan menurun.

Kesejahteraan rumah tangga dapat dihitung dengan menggunakan Good Service Ratio (GSR) yaitu membandingkan pengeluaran konsumsi bahan pangan dengan pengeluaran konsumsi jasa dan pelayanan. Nilai GSR diperoleh dari suatu perbandingan antara jumlah pengeluaran untuk konsumsi bahan pangan (kebutuhan primer) dan konsumsi jasa dan pelayanan (kebutuhan sekunder). Semakin kecil nilai GSR berarti pendapatan yang diperoleh masyarakat semakin banyak yang digunakan untuk memenuhi kebutuhan sekunder (jasa dan pelayanan) setelah kebutuhan primer (Dampa, 2003).

$$
G S \text { Ratio }=\frac{\text { Pengeluaran untuk kebutuhan primer }}{\text { Pengeluaran untuk kebutuhan sekunder }}
$$

Keterangan

GSR $>1$ artinya ekonomi petani kurang sejahtera

GSR $=1$ artinya ekonomi petani sejahtera

GSR < 1 artinya ekonomi petani lebih sejahtera

Soekartawi (1988), mengemukakan bahwa besarnya pendapatan tunai rumah tangga petani merupakan sebagian dari ukuran kesejahteraan rumah tangga petani.Selanjutnya Wie (1980) menjelaskan kemiskinan sebagai suatu keadaan tingkat pendapatan yang tidak mencukupi untuk memenuhi kebutuhan pokoknya yaitu pangan, sandang, pemukiman, kesehatan dan pendidikan.

Pendapatan tunai tumah tangga petani yang amat rendah dapat merupakan indikator kemiskinan/kemelaratan Menurut Esmara (1978) bahwa garis kemiskinan merupakan ukuran pendapatan minimum yang harus dimiliki oleh seseorang atau suatu keluarga agar dapat hidup secara layak yang erat hubungannya dengan konsep kebutuhan dasar manusia.

Patokan garis kemiskinan yang sering digunakan di Indonesia adalah garis kemiskinan yang dikemukakan oleh Sajogyo (1982) yaitu dengan menggunakan tingkat pendapatan per kapita per tahun yang disetarakan ke 
dalam kilogram beras. Batasan kemiskinan menurut Sajogyo adalah sebagai berikut:

1. Miskin sekarat, apabila pendapatan perkapita pertahun $\leq 240 \mathrm{~kg}$ beras di pedesaan atau $\leq 360 \mathrm{~kg}$ beras di perkotaan.

2. Miskin sekali, apabila pendapatan per kapita per tahun 240 - $360 \mathrm{~kg}$ beras di pedesaan dan 360 - $540 \mathrm{~kg}$ beras di perkotaan.

3. Miskin, apabila pendapatan per kapita per tahun $360-480 \mathrm{~kg}$ beras di pedesaan atau $540-720 \mathrm{~kg}$ beras di perkotaan.

4. Tidak miskin apabila pendapatan per kapita per tahun di atas $480 \mathrm{~kg}$ beras di pedesaan atau di atas $720 \mathrm{~kg}$ beras di perkotaan.

\section{Tujuan Penelitian}

Tujuan penelitian adalah mengetahui tingkat kesejahteraan rumahtangga petani jambu mete di Kabupaten Buton.

\section{METODE PENELITIAN}

\section{Lokasi dan Waktu Penelitian}

Metode penelitian adalah metode survey dengan mengambil responden petani jambu mete di Kabupaten Buton. Pemilihan Kabupaten Buton sebagai lokasi penelitian dilakukan secara sengaja (purposive) dengan alasan bahwa di Kabupaten Buton ada enam kecamatan penyumbang terbesar produksi jambu mete. Kemudian dipilih 1 (satu) kecamatan yang memiliki petani jambu mete yang terbanyak. Jumlah sampel yang diambil adalah sebanyak 60 KK. Sampel yang diambil atas pertimbangan, petani yang lancar berbahasa Indonesia dan petani yang mempunyai waktu untuk diwawancarai

\section{Jenis dan Sumber Data}

Pengumpulan data yang dilakukan meliputi data primer dan sekunder. Data primer yang digunakan untuk model pendapatan diperoleh dari hasil kuisioner berdasarkan wawancara langsung dengan petani. Data ini meliputi karakteristik petani, dan keadaan usahataninya.

\section{Pengolahan dan Analisis Data}

Analisis data menggunakan model kontribusi pendapatan dengan menggunakan bantuan perangkat lunak (soft ware) computer. 
ISSN: $1412-8837$

1. Untuk mengetahui kontribusi pendapatan petani jambu mete digunakan persamaan:

$$
\text { Kontribusi Pendapatan }=\frac{\text { Pendapatan Jambu Mete }}{\text { Pendapatan Rumah Tangga Petani }} \times 100 \%
$$

Dengan kriteria sebagai berikut:

Jika kontribusi pendapatan dari jambu mete $<25 \%$ : kontribusinya kecil

Jika kontribusi pendapatan dari jambu mete $25-49 \%$ : kontribusinya sedang

Jika kontribusi pendapatan dari jambu mete 50 - $75 \%$ : kontribusinya besar Jika kontribusi pendapatan dari jambu mete $>75 \%$ : kontribusinya besar sekali.

2. Untuk mengetahui tingkat kesejahteraan rumah tangga diukur dengan menggunakan persamaan GSR (Good Service Ratio) (Nicholson, 1989).

$$
\text { GS Ratio }=\frac{\text { Pengeluaran untuk kebutuhan primer }}{\text { Pengeluaran untuk kebutuhan sekunder }}
$$

dimana:

GSR $>1$ artinya ekonomi petani kurang sejahtera

GSR $=1$ artinya ekonomi petani sejahtera

GSR $<1$ artinya ekonomi petani lebih sejahtera

Selanjutnya diukur dengan menggunakan kriteria Sajogyo (1982) untuk daerah perdesaan yaitu dengan menggunakan tingkat pendapatan per kapita per tahun yang disetarakan ke dalam kilogram beras, dengan kriteria sebagai berikut:

1. Miskin sekarat, jika pendapatan perkapita pertahun $\leq 240 \mathrm{~kg}$ beras.

2. Miskin sekali, jika pendapatan perkapita per tahun 240 - $360 \mathrm{~kg}$ beras.

3. Miskin jika pendapatan perkapita per tahun $360-480 \mathrm{~kg}$ beras.

4.Tidak miskin jika pendapatan perkapita per tahun $>480 \mathrm{~kg}$ beras.

\section{HASIL DAN PEMBAHASAN}

Pendapatan rumah tangga petani adalah pendapatan yang diperoleh petani dari kegiatan usahatani maupun dari luar usahatani. Pendapatan petani jambu mete bersumber dari kegiatan usahatani jambu mete maupun kegiatan selain usahatani jambu mete. 
Tanaman jambu mete merupakan tanaman tahunan yang berproduksi sekali dalam setahun, dalam menanti masa panen tiba untuk memenuhi kebutuhan rumah tangganya petani mencari sumber pendapatan lain diluar kegiatan usahatani jambu mete, dengan harapan total pendapatan rumah tangga menjadi lebih besar dan lebih sejahtera dari segi ekonomi. Sumbangan dari tiap sumber pendapatan petani jambu mete disajikan pada Tabel 1.

Tabel 1. Persentase Pendapatan Rumahtangga Petani Menurut Sumber Pendapatan Di Kabupaten Buton, Tahun 2008.

\begin{tabular}{|c|c|c|}
\hline No & Jenis Sumber Pendapatan & $\begin{array}{c}\text { Rata-rata Pendapatan } \\
(\mathrm{Rp} / \mathrm{th})\end{array}$ \\
\hline 1. & Usahatani Jambu Mete & 1.511 .998 \\
\hline 2. & Selain usahatani Jambu Mete & 1.216 .683 \\
\hline
\end{tabular}

\begin{tabular}{rc}
\hline T o t a 1 & 2.728 .681 \\
\hline
\end{tabular}

Sumber : Analisis Data Petani

Keterangan :- tukang (batu, kayu, dsb)

- buruh (tani, bangunan)

- lain-lain (kiriman, ojek, dsb)

Kontribusi pendapatan usahatani jambu mete terhadap pendapatan rumah tangga petani adalah proporsi pendapatan dari usahatani jambu mete terhadap pendapatan rumah tangga petani. Pendapatan rumah tangga yang dimaksud dalam penelitian ini adalah pendapatan yang diperoleh petani dari usahatani jambu mete dan selain usahatani jambu mete (buruh, tukang dan lainlain).

$$
\begin{gathered}
\text { Kontribusi Pendapatan }=\frac{\text { Pendapatan Jambu Mete }}{\text { Pendapatan Rumah Tangga Petani }} \times 100 \% \\
=\frac{1.511 .998,43}{2.728 .681,76} \times 100 \% \\
=55,41 \%
\end{gathered}
$$


Berdasarkan hasil perhitungan terhadap kontribusi pendapatan jambu mete terhadap pendapatan rumah tangga petani diperoleh hasil kontribusi pendapatan jambu mete sebesar 55,41 persen. Hal ini berarti bahwa 55,41 persen dari pendapatan rumah tangga petani berasal dari pendapatan usahatani jambu mete dan 44,59 persen dari pendapatan rumah tangga petani berasal dari pendapatan di luar usahatani jambu mete, dimana angka tersebut termasuk dalam kategori kontribusi yang besar. Dengan demikian dapat disimpulkan bahwa usahatani jambu mete di kabupaten Buton sangat penting peranannya dalam manunjang pendapatan rumah tangga petani jambu mete.

Ada berbagai indikator yang dapat digunakan untuk mengukur tingkat kesejahteraan seseorang. Indikator dalam penelitian ini kesejahteraan yang dimaksud adalah kesejahteraan ekonomi yang diukur dengan menggunakan dua indikator yaitu pertama diukur dari pendapatan perkapita masyarakat tani petani jambu mete. Kriteria yang digunakan adalah kriteria kemiskinan yang dikemukakan oleh Sajogyo (1982) yaitu dengan menggunakan tingkat pendapatan per kapita per tahun yang disetarakan ke dalam kilogram beras. Kedua dengan menggunakan GSR (Good Service Ratio).

Tabel 2. Distribusi Petani Jambu Mete Berdasarkan Pendapatan Per Kapita Per Tahun Setara Beras di Kabupaten Buton, Tahun 2008

\begin{tabular}{|c|c|c|c|c|}
\hline No & $\begin{array}{l}\text { Golongan pendapatan per } \\
\text { kapita per tahun }(\mathrm{Rp})\end{array}$ & $\begin{array}{l}\text { Kriteria } \\
\text { Kemiskinan }\end{array}$ & $\begin{array}{c}\text { Jumlah } \\
\text { KK } \\
\text { (orang) }\end{array}$ & $\begin{array}{c}\text { Persenta } \\
\text { se }(\%)\end{array}$ \\
\hline 1. & $\begin{array}{c}\leq 648.000 \\
\text { (setara dengan } \leq 240 \mathrm{~kg} \text { beras) }\end{array}$ & Miskin sekarat & 1 & 1,67 \\
\hline 2. & $\begin{array}{c}648.000-972.000 \\
\text { (setara dengan 240-360 kg beras) }\end{array}$ & Miskin sekali & 1 & 1,67 \\
\hline 3. & $\begin{array}{l}973.000-1.296 .000 \\
\text { (setara dengan } 360-480 \mathrm{~kg} \text { beras) }\end{array}$ & Miskin & 6 & 10,00 \\
\hline 4. & $\begin{array}{c}\geq 1.296 .000 \\
\text { (setara dengan } \geq 480 \mathrm{~kg} \text { beras) }\end{array}$ & Tidak miskin & 52 & 86,67 \\
\hline & $\mathrm{Ju} \mathrm{m} \mathrm{lah}$ & & 60 & 100,00 \\
\hline & Rata - rata pendapatan & & \multicolumn{2}{|c|}{2.728 .681} \\
\hline
\end{tabular}

Sumber: Analisis Data Petani

Tabel 2 menunjukkan bahwa sebagian besar yaitu sebesar 86,67 persen petani mempunyai pendapatan per kapita per tahun di atas Rp. 1.296 .000 berarti termasuk kriteria tidak miskin. 
Tabel 3. Rata-rata Pengeluaran Rumah Tangga Untuk Kebutuhan Primer dan Sekunder per Tahun di Kabupaten Buton, Tahun 2008.

\begin{tabular}{clc}
\hline No & \multicolumn{1}{c}{ Jenis Pengeluaran } & Rata-rata (Rp/th) \\
\hline 1 & Kebutuhan Primer & 1.997 .833 \\
2 & Kebutuhan Sekunder & 2.000 .528 \\
\hline & J u m l a h & 3.998 .361
\end{tabular}

Sumber : Analisis Data Petani

$$
\begin{aligned}
\text { GS Ratio } & =\frac{\text { Pengeluaran untuk kebutuhan primer }}{\text { Pengeluaran untuk kebutuhan sekunder }} \\
\text { GS Ratio } & =\frac{1.997 .833}{2.000 .528} \\
& =0,99
\end{aligned}
$$

Berdasarkan hasil perhitungan GSR yaitu perbandingan antara pengeluaran untuk konsumsi bahan pangan (kebutuhan primer) dan pengeluaran untuk konsumsi jasa dan pelayanan (kebutuhan sekunder) diperoleh hasil GS Ratio sebesar 0,99. Berdasarkan kategori yang sudah dibuat, maka angka tersebut tergolong dalam kriteria lebih sejahtera.

\section{Permasalahan Petani dalam Kegiatan Usahatani Jambu Mete}

Khususnya di daerah penelitian pengalaman petani dalam kegiatan usahatani jambu mete sangat bervariasi. Hal ini dikarenakan sebagian kebun jambu mete yang dimiliki petani diperoleh dengan jalan membeli dari petani lain dan sebagian ditanami petani sejak awal penanaman.

Dalam kegiatan usahatani jambu mete ini ada berbagai permasalahan yang dialami petani dalam budidaya jambu mete, utamanya hasil produksi yang diperoleh waktu panen sangat rendah. Dalam hal ini kurangnya tenaga penyuluh untuk memberikan informasi tentang teknologi budidaya jambu mete sehingga petani kurang memahami cara-cara budidaya jambu mete yang baik.

Kegiatan pemangkasan dan pembersihan kebun yang seharusnya dilakukan 2 (dua) sampai (empat) 4 kali setahun jarang dilakukan. Bahkan dari hasil wawancara ada petani yang hanya sekali melakukan pembersihan kebun dan tidak melakukan pemangkasan. Hal ini menyebabkan produksi jambu mete yang dihasilkan sangat rendah.

Sampai dengan penelitian ini dilaksanakan, kegiatan pemupukan dan pemberantasan hama dan penyakit belum dilakukan oleh petani. Hal ini disebabkan karena mereka belum mengetahui pupuk apa yang harus digunakan 
dan cara untuk melakukannya demikian pula halnya dengan obat yang harus digunakan.

Selain itu waktu panen kurang diperhatikan, untuk mendapatkan kualitas biji mete yang baik seharusnya pemetikan buah dianjurkan pada saat buah mete hampir jatuh atau gugur. Namun dalam kenyataannya petani kurang memperhatikan, hal ini dilakukan karena petani diperhadapkan dengan kebutuhan akan uang yang mendesak sehingga mereka ingin untuk cepat mendapatkan uang dari hasil penjualan biji mete.

Pemasaran biji mete bagi petani bukan merupakan suatu permasalahan karena petani dapat memasarkan hasil jambu mete dirumah. Umumnya petani memasarkan hasil metenya dalam bentuk biji kering ke pedagang pengumpul yang datang ke lokasi petani. Harga yang dibayarkan oleh pedagang bervariasi tergantung kualitas jambu mete. Saat panen harga yang diterima petani rendah dibanding harga yang diterima setelah musim panen selesai, rata-rata harga biji mete saat penelitian dilaksanakan adalah Rp. 4.500 per kg. Apabila petani menjual hasil biji metenya pada musim panen selesai akan memperoleh penerimaan yang lebih tinggi.

Namun demikian sekalipun petani menyadari bahwa terdapat perbedaan harga, mereka tetap saja menjual pada saat bertepatan musim panen dengan alasan bahwa mereka membutuhkan uang segera.

\section{SIMPULAN}

\section{Simpulan}

Berdasarkan data dan hasil analisis pada penelitian ini, maka dapat dikemukakan kesimpulan sebagai berikut :

1. Kegiatan usahatani jambu mete memberikan kontribusi yang besar terhadap ekonomi rumah tangga petani jambu mete.

2. Rumah tangga petani jambu mete tergolong sejahtera.

\section{Saran}

1. Mengingat bahwa kegiatan usahatani jambu mete di kabupaten Buton adalah dapat meningkatkan pendapatan dan taraf hidup petani maka dibutuhkan tenaga penyuluh untuk memberikan informasi tentang teknologi budidaya jambu mete agar produksi yang dihasilkan lebih tinggi, sehingga pendapatan lebih tinggi. 
2. Untuk memotivasi petani jambu mete agar dapat meningkatkan pendapatannya dipandang perlu memperhatikan waktu masak (pemetikan buah) serta diadakan grading/sortasi agar harga yang diperoleh lebih tinggi.

\section{DAFTAR PUSTAKA}

Anonim, 2008. Laporan Tahunan 2007 Dinas Perkebunan dan Hortikultura Propinsi Sulawesi Tenggara. Kendari.

Biro Pusat Statistik, 2008. Hasil Pencacahan Lengkap Sensus Penduduk Indonesia Menurut Propins dan Kabupaten/Kodya Seri No.I. Jakarta.

Boediono, 1982. Seri Sinopsis Pengantar Ilmu Ekonomi No.1 Edisi 2. Ekonomi Mikro. BPFE Yogyakarta.

Cahyono, B., 2001. Jambu Mete Teknik Budi Daya dan Analisis Usahatani. Kanisius. Yogyakarta.

Dampa, Y., 2003. Dampak Pengembangan Kakao Bagi Ekonomi Rumah Tangga Tani Arfak di Kabupaten Manokwari. Tesis S2 Program Pascasarjana UGM. Yogyakarta.

Esmara, J. P., 1986. Beberapa Pendekatan dalam Metodologi Penelitian Pembagian Pendapatan di Jakarta. Kertas Kerja pada Konperensi Nasional V Perhepi. Yayasan Agro Ekonomi. Jakarta.

Gray C, P. Simanjuntak, L. K. Sabur, P. F. L Maspaitella, R. C. G, Varley, 1992. Pengantar Evaluasi Proyek. Edisi Kedua, Penerbit PT. Gramedia Pustaka Utama. Jakarta.

Gujarati, D., 1997. Ekonometrika Dasar, Penerbit Erlangga. Jakarta.

Hadisapoetra, Soedarsono, 1973. Biaya dan Pendapatan Usahatani. Fakultas Pertanian Universitas Gadjah Mada. Yogyakarta.

Mubyarto, 1989. Pengantar Ekonomi Pertanian. LP3ES. Jakarta.

Sajogyo, 1982. Menelaah Garis Kemiskinan. Lokakarya Metodologi "Kaji-Tindak" Proyek Pembinaan Peningkatan Pendapatan Petani. Cisarua 20 - 23 Desember 1982. Institut Pertanian Bogor.

Soekartawi, 1988. Prinsip-prinsip Dasar Komunikasi Pertanian. UI Press, Jakarta. 